\title{
RESEARCH PAPER \\ EFFECT OF CHEMICAL AND TIME OF CUTTING OF MILKED YAM MINISETTS ON STORABILITY AND PERFORMANCE OF MINISETTS.
}

\author{
J. K. Okoro \\ University of Agriculture, \\ Department of Crop and Environmental Protection, \\ P. M. B. 2373, \\ Makurdi - Nigeria.
}

\begin{abstract}
The milked yam minisett technology was developed as a rapid method of seed yam multiplication with an advantage of higher, early and uniform sprouting of setts compared to the normal minisett technology. A study was carried out at the Teaching and Research Farm as well as Agronomy Processing and Storage house of the University of Agriculture, Makurdi to test the effect of chemicals and time of cutting of milked yam minisetts on storability and performance of setts in the field. The setts were milked in September and October 2006 and same time in 2007, treated with chemicals and reburied. They were harvested in December and stored for 5 months before planting them out in the field. Results showed that setts milked and cut on October 30 each year recorded the greatest rotting of setts in the month of May of the following year before planting them out in the field, followed by setts milked and cut on September 30. The setts milked and cut on October 15 each year, stored better than the others and had the highest percentage germination in storage. The best treatment among setts milked and cut on September 30 (Monceren) yielded more than the best treatment among setts cut on October 15 (Monceren and rizolex) by about $73.6 \%$ and the best treatment cut on October 30 (Monceren) by about 194.6\%. Also the best treatment among setts milked and cut on October 15 yielded more than the best treatment among setts milked and cut on October 30 by about 69.7\%. So in terms of the storability of setts, the setts milked and cut on October 15 were the best while setts milked and cut on September 30 that survived storage performed best in the field. The best time to milk and cut the setts is between the end of September and mid October. Monceren fungicide performed better than all the other chemicals.
\end{abstract}

Keywords: Milked yam minisetts, milking/cutting time, storage, germination, Yield.

\section{INTRODUCTION}

Yams are among the oldest recorded food crops (Okwor, 1998). It is an important staple food and has ritual and socio-cultural significance (Hahn et al., 1987). The global production of yam is 30.1 million metric tons annually (FAO, 1998). About $90-95 \%$ of this amount is produced in West Africa. Nigeria accounts for about $65-71 \%$ of the world total production (FAO, 1998, Nweke et al., 1991). Before 1970, 
the overall production of yam grew at a faster rate $(6.0 \%)$ than that of cassava $(2.8 \%)$, but today there is a drastic shift in production in favor of cassava (Diehl, 1981). There are fears among the producers and consumers that yam production will decline further in the near future due to limited availability and cost of planting materials, as well as high cost of labor for operations such as land preparation, staking, weeding, harvesting and storage (Asiedu et al., 1998). Also pest and disease problems in the field and store results in relatively high production costs and low tuber yield. The traditional method of using large setts for planting appears uneconomical due to its low multiplication ratio and high cost of planting materials (Okoli et al., 1985).

The minisett technique developed by the $\mathrm{Na}$ tional Root Crop Research Institute Umudike, Nigeria (Okoli and Igbokwe, 1982) to solve the problem of planting materials, has suffered some set backs due to the non-uniform, late and low sprouting rates in the minisetts (Okoli et al., 1985, Okoro and Nwankiti, 2004). A method to overcome these problems militating against the technique has been developed (Okoro, 2009). This trial was to find out the effect of some chemicals and time of milking/ cutting of the newly developed milked yam setts on the storability and germination of the setts.

\section{MATERIALS AND METHODS}

Production of milked yam minisetts: One hundred yam setts weighing approximately $200 \mathrm{~g}$ each (Dioscorea rotundata) were planted on mounds spaced $1 \mathrm{~m}$ apart on the $20^{\text {th }}$ May 2006 and $6^{\text {th }}$ June 2007 at the Teaching and Research farm of the University of Agriculture Makurdi. Plot size was $10 \mathrm{~m} \mathrm{X} 10 \mathrm{~m}$. All agronomic practices were carried out in the plots. Weeding was done twice at 4 and 8 weeks after planting (WAP). There was no fertilizer application and no staking was done. The tubers were carefully milked 3 times, at 2 weeks interval for each milking operation. The three dates of milking were September 30, October 15 and
October 30 for two consecutive years (2006 and 2007). The milked tubers were cut into 25 - $30 \mathrm{~g}$ setts. One hundred cut setts each were treated with the following fungicides, Benlate, Captan, Monceren, Rizolex and wood ash and another 100 setts were not treated and used as control. The milked setts were put inside a bag and the various chemicals were poured on them and shaken well to obtain an even coating of the chemicals on the setts. After the treatment, the setts were re-buried into the mounds where they were taken from and the mounds covered back carefully. The various treatments were properly tagged. After burying the setts, they were left until December 15 before harvesting and storage in both years.

Storage of milked yam minisetts: The milked yam minisetts with properly cured wound periderm were stored in a well aerated room on newspapers spread on the floor. There were 18 treatments (see Table 1) replicated 3 times and arranged in completely randomized design. The setts were monitored in storage and data on monthly percentage germination of setts were recorded. The setts were stored for 5 months in both years after which they were taken to the field for planting. Data taken for both years were combined and subjected to statistical analysis and means separated using least significant differences.

Planting milked setts in the field: The milked minisetts were taken to the field and planted on the $6^{\text {th }}$ June 2007 and 2008. The planting distance was $25 \mathrm{~cm}$ apart on ridges spaced $1 \mathrm{~m}$ apart. Plot size was $2 \mathrm{~m} \mathrm{X} 4 \mathrm{~m}$. There were 18 treatments (Table 2) replicated 3 times and arranged in a randomized complete block design. The plots were weeded at 4 and 8 WAP. No fertilizers were applied and the setts were not staked. Percentage germination of setts was recorded fortnightly and the yield at harvest. Data for both years were combined and subjected to analysis of variance and means separated using the New Duncan's Multiple Range Test (NDMRT). 


\section{RESULTS}

Storage of milked setts: The cumulative monthly percentage rotting/drying of setts in storage for both years are shown in Table 1 . There were significant differences among the treatments for both parameters. Rotting/drying of setts started in March. Only seven treatments recorded rotting/drying of setts in March with setts cut on October 30/Not treated recording the highest percentage rotting of $56.67 \%$, followed by setts cut on October 30/Monceren treated and setts cut on October 15/Benlate treated, which recorded $20 \%$ rotting/drying each. Among the setts cut on September 30, wood ash recorded the highest percentage rotting in March (12.5\%). There was no particular trend in March on the level of rotting between the different periods of milking/cutting and different chemicals used.

In May, the percentage rotting/drying of setts reached $67.2 \%$ for setts cut on October $30 / \mathrm{Not}$ treated which was the highest. All the setts cut on October 30 recorded significant rotting/ drying of setts with all of them recording more than $40 \%$ rotting/drying of setts except the Benlate treated setts which had only $4.35 \%$ rotting of setts. The setts cut on October 15 and treated with Captan, Monceren, and Rizolex did not record any rotting/drying of setts followed by setts cut on September 30. Also among the chemicals used Rizolex and Captan performed better than the others. All setts cut on October 15 and treated with these chemicals did not record any rotting until the month of May.

On percentage germination in storage only 3 treatments recorded germination in March. They include setts cut on September 30/Benlate treated, setts cut on October 15/Rizolex treated, and setts cut on October 15/not treated which recorded $6.03 \%, 8.5 \%$ and $2.13 \%$ germinations respectively. In April setts cut on October 15/ Rizolex treated recorded the highest percentage germination in storage with $77.6 \%$ germination, followed by setts cut on October 15/Rizolex treated and setts cut on October $15 /$ Not treated with $56.67 \%$ and $53.45 \%$ germination respec- tively. In May the setts cut on October 15/ Rizolex treated had $100 \%$ germination in storage followed by setts cut on October 15/Not treated and setts cut on October 15/Captan treated which had $72.2 \%$ and $63.3 \%$ germination respectively. Also in a general note, the setts milked and cut on October 15 performed better than the other times of milking/cutting of setts, and followed by setts milked and cut on September 30.

Table 2 shows the performance of the setts when planted out in the field. At 2 WAP, there were significant differences among the treatments in their percentage germination and yield at harvest. Five treatments recorded over $80 \%$ germination each, with setts cut on October 15/ Rizolex treated recording $100 \%$ germination. All minisetts cut on September 30 recorded over $50 \%$ germination. At 4 WAP most of the treatments recorded over $80 \%$ germination except 5 treatments (setts cut on October 15 and treated with Captan, Monceren, and wood ash, and setts cut on October 30 and treated with Captan, and Monceren) which recorded 78.5\%, $52.8 \%, 56.8 \%, 62.9 \%$, and $69.24 \%$ respectively.

On yield performance, setts cut on September 30 and treated with Monceren and Captan performed best with $4.86 \mathrm{t} / \mathrm{ha}$ and $3.45 \mathrm{t} / \mathrm{ha}$ respectively. This is followed by setts cut on October 15 and treated with Monceren and Rizolex with $2.08 \mathrm{t} / \mathrm{ha}$ each. The setts cut on September 30 performed best followed by setts cut on October 15 . On the performance of chemicals, Monceren, Rizolex and Captan performed best in that descending order.

\section{DISCUSSION}

The milked minisetts stored well from December when it was finally harvested to March when some slight rotting/drying of setts started. This is in line with the earlier work done on the technology (Okoro, 2009). The setts milked and cut on October 15 stored better and recorded less rotting/drying of setts compared to setts milked and cut on September 30 and October 
30. This may be due to the fact that the setts milked and cut on September 30 were from immature tubers which do not store well ordinarily (Onwueme, 1978) while those milked and cut on October 30, though from more matured tubers were not properly cured due to the short period it stayed between the time of cutting and final harvest. The setts milked and cut on October 15 were moderately matured and properly cured and they developed thick periderm that made it impossible for the rot causing organisms to penetrate and destroy the setts. However the setts milked and cut on Sep- tember 30 performed better in the field. This may be due to the fact that the setts which survived long periods of storage were better cured. So despite their physiological immature state, the better curing was advantageous to the setts making them to grow more vigorously and producing the greatest yield at harvest. Comparatively Captan, Monceren, and Rizolex treated setts milked and cut on October protected the setts up till May without any setts rotting (Okoro, 2009).

On the germination of setts, the milked yam

Table 1:Cumulative monthly percentage germination and percentage rotting/drying up of milked yam minisetts in storage in 2007 and 2008

\begin{tabular}{llllll}
\hline Treatments & \multicolumn{3}{c}{ \% rotting/drying of setts. } & \multicolumn{3}{c}{ \% germination in storage } \\
& March & May & March & April & May \\
\hline Setts cut in Sept. 30/Benlate treated. & $2.86 \mathrm{e}$ & $20.25 \mathrm{fg}$ & $6.03 \mathrm{~b}$ & $15 \mathrm{~d}$ & $44.4 \mathrm{c}$ \\
Setts cut in Sept. 30/Captan treated. & $0.0 \mathrm{f}$ & $18.2 \mathrm{~g}$ & $0.0 \mathrm{~d}$ & $9.1 \mathrm{e}$ & $15.5 \mathrm{e}$ \\
Setts cut in Sept. 30/Monceren treated. & $0.0 \mathrm{f}$ & $2.6 \mathrm{~h}$ & $0.0 \mathrm{~d}$ & $13.2 \mathrm{~d}$ & $44.4 \mathrm{c}$ \\
Setts cut in Sept. 30/woodash treated. & $12.5 \mathrm{c}$ & $22.5 \mathrm{f}$ & $0.0 \mathrm{~d}$ & $16 \mathrm{~cd}$ & $55.56 \mathrm{bc}$ \\
Setts cut in Sept. 30/Rizolex treated. & $0.0 \mathrm{f}$ & $23.8 \mathrm{f}$ & $0.0 \mathrm{~d}$ & $0.0 \mathrm{f}$ & $0.0 \mathrm{f}$ \\
Setts cut in Sept. 30/Not treated. & $3.8 \mathrm{~d}$ & $6.47 \mathrm{~h}$ & $0.0 \mathrm{~d}$ & $4.0 \mathrm{e}$ & $27.78 \mathrm{~d}$ \\
Setts cut in Oct. 15/Benlate treated. & $20 \mathrm{~b}$ & $20 \mathrm{fg}$ & $0.0 \mathrm{~d}$ & $22.2 \mathrm{c}$ & $44.4 \mathrm{c}$ \\
Setts cut in Oct. 15/Captan treated. & $0.0 \mathrm{f}$ & $0.0 \mathrm{i}$ & $0.0 \mathrm{~d}$ & $56.67 \mathrm{~b}$ & $63.3 \mathrm{~b}$ \\
Setts cut in Oct. 15/Monceren treated. & $0.0 \mathrm{f}$ & $0.0 \mathrm{i}$ & $0.0 \mathrm{~d}$ & $0.0 \mathrm{f}$ & $0.0 \mathrm{f}$ \\
Setts cut in Oct. 15/woodash treated. & $0.0 \mathrm{f}$ & $4.17 \mathrm{~h}$ & $0.0 \mathrm{~d}$ & $6.25 \mathrm{e}$ & $11.11 \mathrm{e}$ \\
Setts cut in Oct. 15/Rizolex treated. & $0.0 \mathrm{f}$ & $0.0 \mathrm{i}$ & $8.5 \mathrm{a}$ & $77.67 \mathrm{a}$ & $100 \mathrm{a}$ \\
Setts cut in Oct. 15/Not treated. & $2.13 \mathrm{e}$ & $7.3 \mathrm{~h}$ & $2.13 \mathrm{c}$ & $53.45 \mathrm{~b}$ & $72.22 \mathrm{~b}$ \\
Setts cut in Oct. 30/Benlate treated. & $0.0 \mathrm{f}$ & $4.35 \mathrm{~h}$ & $0.0 \mathrm{~d}$ & $0.0 \mathrm{f}$ & $0.0 \mathrm{f}$ \\
Setts cut in Oct. 30/Captan treated. & $0.0 \mathrm{f}$ & $46.81 \mathrm{~d}$ & $0.0 \mathrm{~d}$ & $0.0 \mathrm{f}$ & $0.0 \mathrm{f}$ \\
Setts cut in Oct. 30/Monceren treated. & $20 \mathrm{~b}$ & $62.96 \mathrm{~b}$ & $0.0 \mathrm{~d}$ & $18.51 \mathrm{c}$ & $44.4 \mathrm{c}$ \\
Setts cut in Oct. 30/woodash treated. & $0.0 \mathrm{f}$ & $43.47 \mathrm{e}$ & $0.0 \mathrm{~d}$ & $13.04 \mathrm{~d}$ & $33.3 \mathrm{~d}$ \\
Setts cut in Oct. 30/Rizolex treated. & $0.0 \mathrm{f}$ & $56.67 \mathrm{c}$ & $0.0 \mathrm{~d}$ & $3.33 \mathrm{e}$ & $25 \mathrm{~d}$ \\
Setts cut in Oct. 30/Not treated. & $56.67 \mathrm{a}$ & $67.2 \mathrm{a}$ & $0.0 \mathrm{~d}$ & $10.53 \mathrm{de}$ & $25 \mathrm{~d}$ \\
\hline
\end{tabular}


minisetts began to sprout in storage like any other intact tubers immediately after tuber dormancy was broken (Okoro, 2009). The early sprouting, and high percentage germination of setts recorded has helped to solve the problem of late and low sprouting rates in yam minisett technology. Also all the setts sprouted within 56 WAP, thus ensuring uniform sprouting of setts as against a period of 12 weeks that it takes for the normal minisett to complete spro- uting (Okoro and Nwankiti, 2006).

\section{CONCLUSION}

In conclusion, time of cutting of milked yam minisetts affected their storability, germinability and general performance in the field. The setts cut earlier in the season were better cured than those cut later. Proper curing of setts was necessary for good storability of setts. However, cutting the setts too early in September

Table 2: Cumulative percentage germination of milked yam minisetts in the field and yield at harvest in 2007 and 2008

\begin{tabular}{llll}
\hline \multicolumn{1}{c}{ Treatments } & $\begin{array}{c}\text { Percentage germination } \\
\text { 2WAP }\end{array}$ & WAP & $\begin{array}{c}\text { Yield } \\
\text { t/ha }\end{array}$ \\
\hline Setts cut in Sept. 30/Benlate treated. & $61.11 \mathrm{c}$ & $82.97 \mathrm{bc}$ & $1.1 \mathrm{c}$ \\
Setts cut in Sept. 30/Captan treated. & $50.0 \mathrm{~cd}$ & $83.8 \mathrm{bc}$ & $3.45 \mathrm{a}$ \\
Setts cut in Sept. 30/Monceren treated. & $83.33 \mathrm{a}$ & $100 \mathrm{a}$ & $4.86 \mathrm{a}$ \\
Setts cut in Sept. 30/woodash treated. & $88.89 \mathrm{a}$ & $100 \mathrm{a}$ & $1.38 \mathrm{c}$ \\
Setts cut in Sept. 30/Rizolex treated. & $61.11 \mathrm{c}$ & $94.3 \mathrm{~b}$ & $1.90 \mathrm{c}$ \\
Setts cut in Sept. 30/Not treated(1 $1^{\text {st }}$ control). & $66.67 \mathrm{c}$ & $89.2 \mathrm{bc}$ & $0.65 \mathrm{~d}$ \\
Setts cut in Oct.15/Benlate treated. & $61.11 \mathrm{c}$ & $97.9 \mathrm{a}$ & $0.83 \mathrm{~d}$ \\
Setts cut in Oct. 15/Captan treated. & $65.56 \mathrm{c}$ & $78.5 \mathrm{c}$ & $0.81 \mathrm{~d}$ \\
Setts cut in Oct. 15/Monceren treated. & $11.11 \mathrm{de}$ & $52.8 \mathrm{e}$ & $2.08 \mathrm{~b}$ \\
Setts cut in Oct. 15/woodash treated. & $33.33 \mathrm{~d}$ & $56.8 \mathrm{de}$ & $0.90 \mathrm{~d}$ \\
Setts cut in Oct. 15/Rizolex treated. & $100 \mathrm{a}$ & $100 \mathrm{a}$ & $2.8 \mathrm{~b}$ \\
Setts cut in Oct. 15/Not treated(2 ${ }^{\text {nd }}$ control). & $88.89 \mathrm{a}$ & $95 \mathrm{~b}$ & $0.90 \mathrm{~d}$ \\
Setts cut in Oct. 30/Benlate treated. & $72.22 \mathrm{~b}$ & $96.1 \mathrm{~b}$ & $0.66 \mathrm{~d}$ \\
Setts cut in Oct. 30/Captan treated. & $22.22 \mathrm{~d}$ & $62.9 \mathrm{~d}$ & $1.28 \mathrm{c}$ \\
Setts cut in Oct. 30/Monceren treated. & $66.67 \mathrm{c}$ & $88.97 \mathrm{bc}$ & $1.65 \mathrm{c}$ \\
Setts cut in Oct. 30/woodash treated. & $38.89 \mathrm{~d}$ & $69.24 \mathrm{~d}$ & $1.13 \mathrm{c}$ \\
Setts cut in Oct. 30/Rizolex treated. & $72.22 \mathrm{~b}$ & $92.74 \mathrm{~b}$ & $0.55 \mathrm{~d}$ \\
Setts cut in Oct. 30/Not treated(3 ${ }^{\text {rd }}$ control). & $88.89 \mathrm{a}$ & $90 \mathrm{~b}$ & $0.75 \mathrm{~d}$ \\
\hline
\end{tabular}


has a problem of producing immature milked setts which do not store well naturally (Onwueme, 1978). Also the use of chemicals to treat the setts during milking was an added advantage to the setts. This made the setts to have two levels of protection against rot causing organisms namely, the thick walled wound periderm and the chemicals.

\section{REFERENCES}

Asiedu, R., NG, S. Y. C, Bai, K. V, Ekeayeke, I. J. and Wanyera, N. M. (1998). Genetic Improvement In: Food Yams : Advances in research. Edited by G. C Okwor, R. Asiedu and I. J Ekanayake IITA and NRCRI Ibadan Nigeria 1998, pp. 63-104.

Diehl, L. (1981). Small holder farming systems with yam in the southern guinea savanna of Nigeria. Esehborn, GTZ (Gesellschaft fur Technische zusammen arbeit).

Food and Agricultural Organization (1998). Production Year book. FAO, Rome Italy.

Hahn, S. K., Osiru, D. S. O., Akoroda, M. A. and Atoo, J. A. (1987). Yam production and its future prospects. Outlook on Agriculture 16: $105-110$.

Nweke, F. I., Ugwu, B. O., Asadu, C. I. A. and Ay, P. (1991). Production cost in yam based cropping system of south western Nigeria. Resource and Crop Management Division. Research Monograph No. 6 IITA, Ibadan, Nigeria. 29pp.

Okoli, O. O. and Igbokwe, M. C. (1982). Rapid multiplication of yam by minisett technique. Research bulletin No 2. National Root Crop
Research Institute Umudike Abia State. $12 \mathrm{pp}$.

Okoli, O. O., Ene, L. S. O. and Igbokwe, M. C. (1985). A review of seed yam production by the minisett technique. Proceedings of seventh symposium of International society for Tropical Root Crops, Gosier (Guadelope) 16 July (ED) IWRA, Paris 1985. 425-437.

Okoro, J. K. and Nwankiti, A. O. (2004). Determination of microbial contamination of ware yams and of micro-organisms associated with rotting of yam minisetts. Nigerian Journal of Plant Protection 21: 81-87.

Okoro, J. K. and Nwankiti, A. O. (2006). Evaluation of local plant materials on yam minisetts for the control of soil infection, germination and yield of yam minisetts. Journal of Production Agriculture and Technology, Nassarawa State University, Keffi Nigeria. 2 (2): 50-55.

Okoro, J. K. (2009). Overcoming the nonuniform, late and low sprouting rates in yam minisetts by the use of milked setts. African Journal of Root and Tuber Crops 7 (1) :23-26

Onwueme, I. C. (1978). The Tropical tuber crop. Yams, cassava, sweet potato and cocoyams. John Wiley and sons, New York U.S.A 234pp.

Okwor, G. C. (1998). Importance of yams. Pages 1-12 in Food yams, Advances in research edited by G.C Okwor. R. Asiedu and I. J. Ekanayake. IITA and NRCRI, Ibadan Nigeria. 